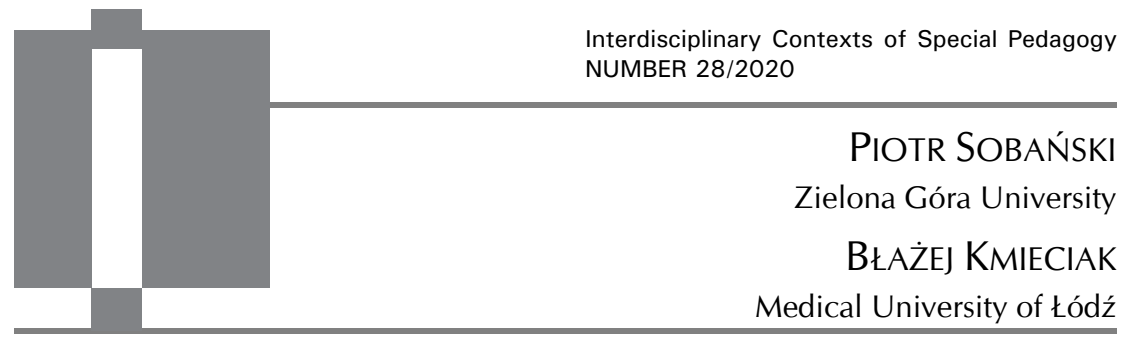

\title{
"When Law Forgets About Dignity": Selected Historical and Modern Contexts of Sterilisation of People with Disabilities
}

\begin{abstract}
Piotr Sobański, Błażej Kmieciak, "When Law Forgets About Dignity": Selected Historical and Modern Contexts of Sterilisation of People with Disabilities. Interdisciplinary Contexts of Special Pedagogy, no. 28, Poznań 2020. Pp. 129-148. Adam Mickiewicz University Press. ISSN 2300-391X. e-ISSN 2658-283X. DOI: https://doi. org/10.14746/ikps.2020.28.07
\end{abstract}

What is human dignity? How to define the dignity of a person? Is it possible to identify key features that show the principles of respecting the dignity of another person? Attempts to define the concept indicated here may inevitably fail. On the one hand, human dignity is a universal concept. It refers to all people. Nevertheless, on the other hand, each of us has our own sense of dignity. Paradoxically, e.g., humiliation of a particular person's dignity shows us the importance of the area that has been violated. Similar violations often affect sick and disabled persons. Examples of similar activities throughout human history abound. In this context, special attention should be paid to the interventions undertaken by the Nazis before the outbreak of WWII. Here, we are talking especially about mass and legalised activities that resulted in the sterilisation of many thousands of people with intellectual disabilities, people with physical disabilities and people experiencing mental disorders. The Nazi practices indicated here are presented as examples of human right violations. At the same time, they are examples of the unlawful rule of the state over an individual. Is there still a danger of reverting to similar practices today? Can standards of respect for human rights created years ago successfully protect disabled people against violation of their dignity? Can the knowledge of Nazi activities 
still be important to us? The presented article is intended as an attempt at answering these questions.

KEY WORDS: human dignity, sterilisation of disabled people, human rights, eugenics, suffering

\section{Preliminary Remarks}

In mid June 2019, the British media informed the public about a court-ordered abortion for a disabled woman. The woman was 22 weeks pregnant. As noted in press telegrams, the woman was diagnosed with mental disability in a degree that made her independent ${ }^{1}$ existence impossible. It was written: The woman did not have the mental capacity for making an independent decision about the pregnancy, even though she claimed that she wanted to have the baby. The judge adjudicating in the case stated that: I think that (the womanauthors' note) would like to have a baby as if it was a nice doll (...). I am deeply aware of the fact that ordering abortion by the state at the moment when it seems that the woman does not want it is a deep intervention. However, I have to act in her best interest and not under the impact of the society. ${ }^{2}$ The aforementioned decision of the British court met with strong criticism. In the first place, it must be noted that the compulsory abortive measures were taken against the will of the pregnant woman, her mother (a midwife) who was caring for her, and social service employees. In the second place, attention should be drawn to the character of the procedure. Here, we are talking about a forceful abortion which - independently from the degree of legalisation has to be called a special type procedure. It is a medical intervention

${ }^{1}$ In the presented paper, the term "mental disability" will be used. It is a part of the Polish legislation, including the Act on Protection of Mental Health, to which the authors will refer in a further part of this paper.

${ }^{2}$ Quoted after telegram: Brytyjski sad nakazat aborcję niepetnosprawnej kobiecie, “TVP. Info", source: https://www.tvp.info/43208459/brytyjski-sad-nakazal-aborcjeniepelnosprawnej-kobiecie [accessed: 14 January 2020]. 
that terminates a unique biological period in a woman's life. ${ }^{3}$ In the case discussed here, an appeal was lodged. Its effect was rejection of the judgement of the first instance. Hence, the disabled patient was allowed to continue her pregnancy. 4

As mentioned before, the presented case met with strong criticism from representatives of religious milieus. Several Catholic bishops, including John Keenan and John Sherrington, drew attention to the fact that the court's consent for compulsory abortion with respect to a handicapped woman was an example of the state overstepping its authority in relation to an individual. It was noted that this was a radical move, violating an individual's fundamental rights. This opinion was soon shared by almost 120,000 people who signed a petition with respect to the disabled patient. ${ }^{5}$ However, as it turns out, planned and compulsory termination of pregnancy of the aforementioned woman also sparked strong protests among people not related to, e.g. the Catholic Church that straightforwardly criticises abortion. Mainstream media related the case in detail, referring to the blatant injustice of the court's decision and its cruel nature. ${ }^{6}$ However, several questions appear here. Why did such criticism emerge? Why did the abortion-related plans of the court encounter social resentment in a country where abortion is accepted as a reproductive measure and its use is commonly available until the $24^{\text {th }}$ week of pregnancy? Furthermore, is it justified to compare

${ }^{3}$ Cf. in this context: Y. Joseph U.K. Court Says Mentally Disabled Woman Must Have Abortion, "New York Times", https://www.nytimes.com/2019/06/23/world /europe/abortion-mentally-disabled-uk.html [accessed: 14 January 2020].

${ }^{4} \mathrm{H}$. Sherwood, Appeal Court Overturns Forced Abortion Ruling, "The Guardian", https://www.theguardian.com/world/2019/jun/24/catholic-church-hits-out-at-co urt-over-abortion-ruling [accessed: 14 January 2020].

${ }^{5}$ F. Mikelionic, British Court Overturns Ruling Forcing Disabled Pregnant Woman to Have Abortion, "Fox News", https://www.foxnews.com/world/british-overturnruling-forcing-disabled-pregnant-woman-public-uproar [accessed: 14 January 2020].

${ }^{6}$ Telegram: U.K. Court of Appeal Overturns Ruling Ordering Mentally Disabled Woman to Have Abortion, "The Wall Street Journal", https://www.wsj.com/articles/ u-k-court-rules-mentally-disabled-woman-must-have-abortion-11561390581 [accessed: 14 January 2020]. 
such ruling of the British court to the despicable actions of physicians during the times of the Third Reich who, based on specific provisions, undertook sterilisation measures with respect to disabled persons?

The doubts presented here are born naturally. In the recent years, it has been difficult to encounter a case where a court would accept abortion for a mentally disabled patient without her consent. It must also be added that in the aforementioned case, the court ruling was supported by an opinion of three physicians: an obstetrician and two psychiatrists who arbitrarily decided that termination of pregnancy would bear semblance of therapy for the patient. It was ascertained that its continuation could lead to a threat for the mental health of the aforementioned woman. ${ }^{7}$

Comparing the currently undertaken activities with the procedures that were carried out by the Third Reich physicians may evoke surprise. The case presented here clearly directs us to the times when thousands of Germans were deprived of the capacity to procreate solely and exclusively due to the fact that they were diagnosed with an intellectual disability, mental disease, addiction or disruptions in social functioning. It may come as a surprise to many that the Nazi procedures were very well described, as well as "efficiently" constructed. They did not refer to an arbitrary decision of, e.g., an NSDAP official; cases were directly sent to courts, which was composed not only of lawyers, but also of physicians.

The authors of the paper will try to discuss the aforementioned Nazi practices, in particular court procedures pertaining to the sterilisation of disabled persons. It is not only meant to recall the important facts that straightforwardly show the situation of violation of human rights, but also to indicate the modern contexts of similar interventions. The analyses and reflections below - also relying on the British example presented above - will form a basis for answer-

7 A. Yuhas, U.K. Appeals Court Overturns Order for Mentally Disabled Woman to Have Abortion, "New York Times", https:/ / www.nytimes.com/2019/06/24/world/ europe/uk-abortion-mentally-disabled-woman.html [accessed: 14 January 2020]. 
ing the following question: are legal procedures a sufficient tool that allows for securing a person's dignity, including people who suffer from disabilities? The authors of the paper primarily use the historical and legal method, along with an analysis of reference materials, supported by the study of the content of mass media communications. Thus, the text features numerous references to Internet sources. As it turns out, the presented subject is broadly discussed by researchers - primarily German - who present their findings on an ongoing basis on the Internet. 8

\section{Legal Bases of Sterilisation in the Third Reich}

On 14 July 1933, the Law for the Prevention of Offspring with Hereditary Diseases was signed in Berlin by Adolf Hitler, Chancellor of the Reich, Wilhelm Frick, Minister of Internal Affairs and Franz Gärtner, Minister of Justice. ${ }^{9}$ The Law entered into force on 1 January 1934. ${ }^{10}$ Standards contained in the Law were addressed to persons who were deemed handicapped. The content of the official grounds for adoption of the Law stipulated that sterilisation was meant to exclude offspring of biologically lesser value from the society. Its intention was to prevent birth of children whose parents were treated as handicapped, hereditarily burdened and furthermore, there was a potential risk of reproduction in an uncontrolled mode. ${ }^{11}$

${ }^{8}$ About the selected methods cf.: M. Krajewski, O metodologii nauk i zasadach pisania naukowego, Płock, 2010, p. 23, M. Furmankiewicz, P. Ziuziański “Internet jako źródło danych epidemiologicznych", [in:] Rola informatyki w naukach ekonomicznych i społecznych Innowacje i implikacje interdyscyplinarne, Z. E. Zieliński (ed.), Wydawnictwo Wyższej Szkoły Handlowej Kielce, 2013, p. 379, K. Puchalski, “Internet a możliwości poprawy efektów edukacji zdrowotnej”, Studia Edukacyjne, No. 23, 2012, p. 121.

${ }_{9}^{9}$ Gesetz zur Verhütung erbkranken Nachwuchses vom 14. Juli 1933 (RGBl I, p. 529).

$10 \S 18$ of the Law.

11 G. Bock, Zwangssterilisation im Nationalsozialismus. Studien zur Rassenpolitik und Geschlechterpolitik, p. 4 (https://refubium.fu-berlin.de/bitstream/handle/fub188/23 087/Zwangssterilisation_im_Nationalsozialismus.pdf) [accessed: 14 October 2019]. 
Pursuant to $\S 1(1)$ of the Law, sterilisation via a surgical procedure applied to persons who were deemed to have a hereditary disease if, based on medical knowledge, it was to be expected with significant probability that the descendants of such person would suffer from grave physical or psychical defects of hereditary nature. $\S 1(2)$ of the Law included a catalogue of hereditary diseases within the meaning of the provisions of the Law. They included: congenital mental deficiency, schizophrenia, manic-depressive insanity, hereditary epilepsy, hereditary chorea, hereditary blindness, hereditary deafness, as well as any severe hereditary deformity. Additionally, persons suffering from severe alcoholism could also be sterilised (§ 1(3) of the Law). Provisions of the Law also referred to five psychiatric and neurological diagnoses, three types of physical disability and alcoholism. ${ }^{12}$ In the case of alcoholism as one of the causes of sterilisation, it was not about the determination how often and in what quantities a given person drank alcohol. The decisive criterion was the person's social behaviour. ${ }^{13}$ Thus, there was also a risk of sterilisation in case of refusal to comply with the schooling obligation, prior criminal record and homelessness. ${ }^{14}$

Mental deficiency referred to in $\S 1(1)$ of the Law was actually treated as a social category and not a medical and psychiatric one. ${ }^{15}$ The general concept of mental deficiency contained in the Law

12 H.M. Schneider, Das nationalsozialistische "Gesetz zur Verhütung erbkranken Nachwuchses" am Beispiel der 1939 an der Psychiatrie Tübingen durchgeführten Sterilisationsgutachten, p. 9 (https://publikationen.uni-tuebingen.de/xmlui/bitstream/hand le/10900/46141/pdf/finale_druckversion_nach_druckfreigabge_und_korrektur_dis _h_schneider_pdf_a_.pdf?sequence=1) [accessed: 16 October 2019].

13 C.A. Spring, Zwischen Krieg und Euthanasie: Zwangssterilisationen in Wien 19401945, p. 67 (http://www.boehlau-verlag.com/download/161614/978-3-205-783213_OpenAccess.pdf) [accessed: 15 October 2019].

14 W. Ayass, "Asozialer Nachwuchs ist für die Volksgemeinschaft vollkommen unerwünscht". Die Zwangssterilisationen von sozialen Außenseitern (https://kobra.uni-kas sel.de/bitstream/handle/123456789/2007013016913/Zwangssterilisation.pdf;jsessionid =50FFAF621A85CF83434FC236F3ADD2DD?sequence=3) [accessed: 15 October 2019].

${ }^{15} \mathrm{~K}$. Berndt, Zwangssterilisationen in Mannheim. Die Rolle der Richter und Ärzte, p. 3 (http:/ / akjustiz-mannheim.de/Informationen \%20zur\%20Zwangssterilisation\%20im $\% 20 \mathrm{NS} \% 20 \mathrm{in} \% 20 \mathrm{Mannheim}$.pdf) [accessed: 14 October 2019]. 
opened the possibility of constructing divergences from social or character-related standards based on non-scientific and subjective evaluations, whereas such structure could be legitimised with the use of a medical diagnosis of oligophrenia. ${ }^{16}$ Applications for sterilisation could be filed by persons who wished to undergo the procedure or their statutory representatives (§ 2(1) of the Law). Medical practitioners, as well as directors of psychiatric clinics, care homes and penitentiary facilities were also vested with the right to file an application for sterilisation of a given person $(\S 3(1)$ and (2) of the Law). Even though directors were authorised to file applications, yet they often chose a different path, i.e. they filed a report to the Health Authority (Gesundheitsamt), which allowed them to remain anonymous. ${ }^{17}$

It must be emphasised that even a brief stay in a psychiatric facility was a basis for instituting proceedings on compulsory sterilisation. Even if the patient left the facility due to mitigation of disease symptoms, there was a risk of initiation of proceedings. ${ }^{18} \S 3$ of the Law allowed for submission of applications for initiation of the procedure in case of persons who were in a penitentiary facility. Sterilisation of criminals was a justified necessity with respect to the broadly understood protection of the society, in particular children and women, from rape and unwanted pregnancy. ${ }^{19}$

\section{Procedure Before the Sterilisation Court of First Instance}

Pursuant to $\S 4$ of the Law, an application for sterilisation was to be submitted in written form or accompany the minutes in a Hered-

${ }^{16}$ E. Heesch, Nationalsozialistische Zwangssterilisierungen psychiatrischer Patienten in Schleswig-Holstein (http://akens.org/index.php/materialien-zur-zeitgeschichte/aufsaet ze/18-aufsaetze/euthanasie-zwangssterilisierungen.html) [accessed: 14 October 2019].

17 J. Piechatzek, Die Auswirkungen des Gesetzes zur Verhütung erbkranken Nachwuchses an der Universitäts-Frauenklinik Kiel in der Zeit von 1932 bis 1940, p. 15 (https://d-nb.info/1019866705/34) [accessed: 15 October 2019].

${ }^{18}$ E. Heesch, op. cit.; W. Ayass, op. cit.

${ }^{19}$ H.M. Schneider, op. cit., p. 22. 
itary Health Court. The application also had to include a medical opinion or the necessity of sterilisation had to be substantiated in another mode. It is worth adding that an application filed by a person wishing to undergo the sterilisation or his/ her legal representative could have been withdrawn ( $\$ 2(3)$ of the Law). It should also be taken into account that in reality, submission of applications for sterilisation of own person was a rarity ${ }^{20}$. Jurisdiction of the Hereditary Health Court was specified in $\S 5$ of the Law. This was the court having competence as to any cases instituted against a given person, in this case a person who was going to be sterilised, unless the provisions stipulated special competence. In 1936, 205 of courts of this type operated in the Reich. ${ }^{21}$

The Hereditary Health Court was a division of a District Court (Amtsgericht). The adjudicating panel comprised a professional judge as the presiding officer, a medical officer and a physician who received the approval of the German Reich, i.e. was vested with the full right to practise the profession and also had in-depth knowledge about the hereditary health science. An alternate was appointed for every member of the panel. The presiding officer was excluded if he/ she previously rendered a decision in a Guardianship Court in proceedings on granting permit for sterilisation referred to in § 2(1) of the Law. On the other hand, the medical officer was excluded if he filed an application to the Hereditary Health Court for sterilisation ( $\$ 6(1)$ of the Law).

The proceedings of the Court were not public $(\S 7(1)$ of the Law). It must be emphasised that persons to whom the procedure on sterilisation referred did not have insight to the case files. ${ }^{22}$ The content of $\S 7(2)$ of the Law stipulated significant freedom of the Hereditary Health Court with respect to evidentiary proceedings. The Court could allow evidence from testimonies of witnesses and experts and order examination of the person to whom the application for sterilisation referred. Such person could have been compul-

\footnotetext{
${ }^{20}$ C.A. Spring, op. cit., p. 185.

${ }^{21}$ G. Bock, op. cit., p. 213.

22 E. Heesch, Nationalsozialistische...
} 
sorily brought to a psychiatric clinic. If patients tried to escape during the proceedings, they were looked for by the police. ${ }^{23}$

Physicians who appeared before the Court as witnesses or experts were, pursuant to $\S 7(2)$ of the Law, released from the obligation of observing professional secrecy. This statutory provision resulted, in the majority of cases, in a drastic drop or even lack of trust of patients to physicians. ${ }^{24}$ The Hereditary Health Court could have applied to court and administrative authorities and hospitals for information useful for the needs of the proceedings, the disclosure of which was mandatory at the Court's request.

Pursuant to $\S 8$ of the Law, the Court issued judgements at its absolute discretion based on results of proceedings and evidence taken. A judgement in the case was made after an oral discussion, with the majority of votes. The Court had a significant margin of freedom when issuing judgements. ${ }^{25}$ It should be borne in mind that during the court proceedings, Nazi judges and physicians cooperated closely. ${ }^{26}$ Physicians not only issued judgements in cases, but also acted as prosecutors, filing applications for sterilisation. Apart from it, psychiatrists issued opinions in proceedings which were usually in favour of sterilisation. This testifies to a significant role of physicians in execution of the provisions of the Law. ${ }^{27}$ At the same time, it must be added that as long as the issue of a judgement took place in compliance with the stance of the majority of the adjudicating panel, it was not the judge's task to settle differences in the opinions of physicians in the area of medicine. ${ }^{28}$

${ }^{23}$ Ibidem.

24 C.A. Spring, op. cit., p. 115.

${ }^{25}$ Cf. Ibidem, p. 272.

${ }^{26}$ T. Foth, Regieren durch Akten. Die Funktion von PatientInnenakten für die Krankenmorde des Nationalsozialismus, [in:] Strukturentstehung durch Verflechtung. AkteurenNetwerk-Theorie(n) und Automatismen, (eds.) T. Conradi, H. Derwanz, F. Muhle, Wilhelm Fink Verlag, München 2011, pp. 219-235.

27 E. Heesch, Zwangssterilisierungen Kranker und Behinderter in Schleswig-Holstein (http:/ / akens.org/index.php/materialien-zur-zeitgeschichte/aufsaetze/18-aufsaet ze/euthanasie-zwangssterilisierungen.html) [accessed: 14 October 2019].

${ }^{28}$ Cf. J. Piechatzek, op. cit., p. 16. 
It must be noted that $\S 8$ of the Law imposed on the Court an obligation of preparing a judgement in written form along with grounds, including causes, on the basis of which sterilisation was ordered or the application was dismissed. Copies of the judgement had to be served to the applicant, the medical officer and the person with respect to whom an application for sterilisation was made, alternatively his/ her statutory representative, if such person was not authorised to file an application pursuant to $\S 2$ of the Law. Proceedings usually took place in the absence of persons whom the application for sterilisation referred to. ${ }^{29}$

Pursuant to $\S 13(1)$ of the Law, a person subject to sterilisation did not bear the costs of court proceedings. On the other hand, $\S 15(2)$ of the Law imposed the obligation of secrecy on persons participating in court proceedings, violation of which was punishable by imprisonment up to 1 year or a money fine. At the same time, it is to be acknowledged that the obligation of secrecy also included persons who were going to be sterilised under pain of penalty. ${ }^{30}$ Filing a motion for prosecution instituted proceedings ex officio. In such case, personnel, employers, physicians, including persons who were suspected of committing a forbidden deed under $\S 15(2)$ of the Law were heard. ${ }^{31}$

\section{Appeal Procedure and Resumption of Procedure}

Pursuant to $\S 9$ of the Law, it was possible to appeal against a judgement of the Hereditary Health Court. The appeal had to be lodged in written form or orally to the minutes in the secretariat of the Court of first instance within a month from serving of the decision. However, there was a possibility of reverting the date for filing the appeal. Effective submission of appeal resulted in suspension of

\footnotetext{
${ }^{29}$ C.A. Spring, op. cit., p. 32; J. Piechatzek, op. cit., p. 15.

${ }^{30}$ E. Heesch, Nationalsozialistische...

${ }^{31}$ H.M. Schneider, op. cit., p. 29.
} 
execution of the judgement ( $\S 9$ of the Law). Pursuant to amendment of the Law of 14 July 1933, made via Act of 26 June 193532, the allotted term for submission of appeal was shortened from one month to 14 days, which was justified by the welfare of the proceedings. 33

The Higher Hereditary Health Court, established as the Court of second instance, was a division of the Court of Appeals (Oberlandesgericht). In 1936, there were 18 courts of second instance. ${ }^{34}$ The composition of a Higher Hereditary Health Court included: a judge of the Court of Appeals, a medical specialist, as well as a national licentiate physician of proved competence in hereditary health learning. For every member of the adjudicating panel, an alternate was appointed, analogously to the proceedings before the Court of first instance, which followed from the content of $\S 6(1)$ of the Law of 14 July 1933.

Pursuant to $\S 10(2)$ of the Law, the proceedings before the Higher Hereditary Health Court were governed by provisions of $\S 7$ and 8 of the Law. Just as the Hereditary Health Court, the Court of second instance also adjudicated during a non-public session. With respect to evidentiary proceedings, there was a possibility of hearing witnesses, experts and the person who was going to be sterilised. In case the necessity of medical examination of such person was acknowledged, in case of the person's un-excused absence, the competence of the Court of second instance also included a warrant for compulsory appearance at the next examination date. Physicians were exempt from medical confidentiality, whereas authorities and hospitals were required to provide the Court with any requested information.

A Higher Hereditary Health Court issued judgements at its absolute discretion, taking into account the overall evidentiary proceedings that were carried out. Issue of a judgement took place after

\footnotetext{
32 RGBl I, p. 773.

${ }^{33}$ G. Bock, op. cit., p. 215.

34 Ibidem, p. 213.
} 
an oral discussion, by majority of votes of the adjudicating panel. The judgement had to be prepared in written form, along with grounds indicating the causes for acknowledging the application for sterilisation or its dismissal.

In spite of the possibility of submission of appeals by persons who were going to be subjected to sterilisation guaranteed in the Law, in practice the courts of second instance never acknowledged them. ${ }^{35}$ The decision of the Higher Hereditary Health Court had to be served to the entities listed in the content of $\S 8$ of the Law. Even though judgements of the Court of second instance were final (§ 10(3) of the Law), yet there was a possibility of submission, pursuant to $\S 12(2)$ of the Law, of an application for resumption of proceedings both at the benefit and to the detriment of the person who was going to be sterilised. If circumstances requiring renewed review of the actual status came into being, the Hereditary Health Court was required to resume the proceedings and temporarily suspend the sterilisation. In case of dismissal of the application, the proceedings were permitted only in case of emergence of new facts justifying performance of sterilisation.

\section{Enforcement of Final and Valid Decisions of Sterilisation Courts}

The surgical procedure of sterilisation could be performed at a hospital by a physician fulfilling the requirements set out in $\S 11$ of the Law. With respect to performance of the procedure, a physician who filed an application for sterilisation or who participated in the court proceedings as a member of the adjudicating panel was excluded. Persons who did not file the application for sterilisation on their own and who evaded the obligation of its performance

35 S.L. Herrmann, K. Braun, Das Gesetz, das nicht aufhebbar ist. Vom Umgang mit den Opfern der NS-Zwangssterilisation in der Bundesrepublik (https://www.kj.no mos.de/fileadmin/kj/doc/2010/KJ_10_03_07.pdf) [accessed: 15 October 2019]. 
could have been forcefully brought by the police. Means of physical coercion could have been used with respect to them in a situation when all other means turned out to be insufficient ( $\S 12(1)$ of the Law). Use of coercion was not only permitted, but often used in practice. ${ }^{36}$ Victims of sterilisation policy did not have the possibility of defending against enforcement of final and valid judgements of the Hereditary Health Court. ${ }^{37}$ It is worth adding that between 1934 and 1936, approx. 7-9\% of patients were forcefully brought by the police for the purpose of performance of the surgical procedure ${ }^{38}$. Pursuant to $\S 12(1)$ of the Law, the procedure could have been performed if the judgement of the Court ordering sterilisation became final and valid. A physician performing the procedure was required to provide the medical specialist with a written report on the course of the sterilisation along with information about the applied method. The report had to be presented within two weeks from the procedure. 39

As a result of second amendment of the Law of 14 July 1933, made by Law of 4 February 1936, sterilisation of women above 38 years of age was also allowed with the use of X-rays. ${ }^{40}$ For women over 38 years of age, surgery operation was considered too risky. ${ }^{41}$ Sterilisation was also performed with the use of radioactive radiation, in particular radium, mesothorium and radon. ${ }^{42}$

It must be added that in line with $\S 14$ of the Law of 14 July 1933, there was a possibility of sterilisation omitting the provisions of the Law in case of threat to life or health. In such case, sterilisation could be performed by removal of gonads. The procedure had

36 Ibidem.

37 A. Scheulen, Zur Rechtslage und Rechtsentwicklung des Erbgesundheitsgesetzes 1934 (https:/ / www.bruecke-sh.de/beitrag/anhang/Rechtslage.pdf) [date of access: 15 October 2019].

38 E. Heesch, Nationalsozialistische...

${ }^{39}$ J. Piechatzek, op. cit., p. 17.

${ }^{40}$ RGBI I, p. 119.

${ }^{41}$ H.M. Schneider, op. cit., p. 33.

42 J. Piechatzek, op. cit., s. 16; H.M. Schneider, op. cit., p. 34. 
to be carried out in line with the rules of medicine and at the consent of the person who was going to be sterilised.

The Law of 4 February 1936 introduced $\S 10$ a to the Law of 14 July 1933, which referred to the issue of sterilisation of pregnant women. A situation where the nasciturus was deemed capable of living and the situation where the nasciturus was not capable of living were regulated separately. In this respect, $\S 10 \mathrm{a}(2)$ of the Law introduced a definition of incapacity for life. It ended at the lapse of the $6^{\text {th }}$ month of pregnancy. $\S 11$ and 14 of the Law also included provisions which referred to termination of pregnancy. ${ }^{43}$ It must be emphasised that it did not matter whether a woman was pregnant at the time of issue of the court judgement. It was sufficient for the pregnancy to exist at the moment of performance of the sterilisation procedure. The concept of combined abortion and sterilisation was dictated both by the risk that a pregnant woman would have to endure during performance of two separate procedures, as well as the necessity of minimising the costs of enforcement proceedings. ${ }^{4}$ Analogously to court proceedings, Art. 15(2) of the Law imposed the obligation of secrecy on persons participating in the court proceedings, violation of which was punishable by imprisonment up to 1 year or a money fine.

\section{Discussion and Final Remarks}

The sterilisation policy was a form of racism. Racism not only entails discrimination of other nations, but also discrimination of members of own nation who are considered handicapped. The concept of race promulgated by the Nazi did not entail - in spite of glorification of the German nation - that race was already given, but that it had to be created. ${ }^{45}$ From the Nazi point of view, the sterilisa-

\footnotetext{
${ }^{43}$ More about it: E. Heesch, op. cit.

${ }^{44}$ J. Piechatzek, op. cit., p. 17.

${ }^{45}$ G. Bock, op. cit., p. 12; A. Scheulen, op. cit.
} 
tion procedure was not about putting the state interest above the interest of individuals. Such interests were treated as identical and it was assumed that no conflict existed between them in theory. An individual had no reason to give birth to sick children and the society had no reason to sterilise healthy individuals. ${ }^{46}$ It must also be mentioned that reduction of procreation of mentally and physically sick people was meant to reduce the burden on the state budget. ${ }^{47}$ Furthermore, regulations contained in the Law, apart from fulfilment of the racist policy, were intended at prosecuting and sanctioning any socially undesirable behaviour. Therefore, persons manifesting stances not accepted by the Nazi were often diagnosed as sick, suffering from congenital mental deficiency. This referred to political opposition in a significant degree. Apart from mental retardation, also a diagnosis of severe alcoholism was meant to acknowledge any behaviour not fitting the concept of a Nazi state as a criterion enabling sterilisation. ${ }^{48} \mathrm{G}$. Bock refers to data indicating that until the outbreak of WWII, 375,000 people were sterilised. ${ }^{4} 9$ The outbreak of the war brought a short-term suspension, and subsequently resumption, in a limited scope, of sterilisation procedures. ${ }^{50}$ In total, as a result of application of the Law between 1934 and 1945, approx. 400,000 people were sterilised. ${ }^{51}$ Independently from the above, an unknown, yet significant number of people was sterilised in omission of the provisions of the Law, often against their will, and even without their knowledge. ${ }^{52}$ When trying to de-

${ }^{46}$ G. Bock, op. cit., p. 215.

47 G. Bock, op. cit., p. 83.

${ }^{48}$ E. Heesch, Zwangssterilisierungen...

${ }^{49}$ G. Bock, op. cit., p. 248.

50 C.A. Spring, op. cit., p. 72.

51 Cf. R. Loddenkemper, N. Konietzko, V. Seehausen, Die Lungenheilkunde und ihre Institutionen im Nationalsozialismus, Pneumologie 72 (02), 2018, p. 112; J. Nedoschill, R. Castell, "Kindereuthanasie" während der nationalsozialistischen Diktatur: Die "Kinderfachabteilung" Ansbach in Mittelfranken, Praxis der Kinderpsychologie und Kinderpsychiatrie 50(3), 2001, p. 194-195; G. Bock, op. cit., p. 4; T. Foth, op. cit., p. 219 et seq.

52 G. Bock, op. cit., p. 4. 
termine the exact number of victims of forcible sterilisation, it is necessary to bear in mind that publication of data about the number of victims was forbidden by the Ministry of Propaganda of the Third Reich. The authorities were aware of the risk that too high number of sterilisation proceedings could make the German society anxious. ${ }^{53}$

The practice described above evokes justified social resentment. This is an example of humiliating treatment of a selected group of people on account of specific features which were arbitrarily deemed bad or detrimental. Analysis of the provisions of Nazi laws leads to a surprising conclusion. The Nazis were very precise in their legislative activities. Sterilisation from the perspective of literal wording of legal acts was meant to be an exceptional procedure, performance of which had to be preceded by an adequate court analysis. Such procedure may at times evoke surprise also among modern experts on human rights, including rights of people with disabilities. As shown above, a decision on depriving a given person of fertility was made by a court supported, in fact, by opinions of several physicians. A participant of the procedure who did not agree with the judgement could appeal to a court of higher instance. Compulsory sterilisation (without the court's control) was considered an exceptional phenomenon in the Nazi legislation. It could be justified by, e.g., such important situation as the necessity of depriving a person of fertility on account of a threat to his/ her life. Thus, as can be seen, it is surprising that the legislation of the Third Reich took into account the right of the procedure's participant to trial, information, effective appeal measures and medical actions taken by qualified medical personnel. Therefore, how is it possible that the procedures and actions discussed here became one of the key cases of violation of dignity of sick and disabled people?

The answer to the question posed here lies primarily in the term "dignity." The Nazi provisions relied on an assumption in line with which not every person was vested with full human dignity. Eugen-

${ }^{53}$ E. Heesch, op. cit. 
ic assumptions of the Third Reich consisted, on the one hand, of the worship of "Übermensch" and on the other on the contempt for everything that was weak, sick and disabled. In this respect, assumptions presented by Friedrich Nietzsche were of essence. In "On the Genealogy of Morality", Nietzsche claims: "Away with this disgraceful mollycoddling of feeling! That the sick should not make the healthy sick - and this would be that kind of mollycoddling - ought to be the chief concern on earth: - but for that, it is essential that the healthy should remain separated from the sick, should even be spared the sight of the sick so that they do not confuse themselves with the sick. Or would it be their task, perhaps, to be nurses and doctors? ... But they could not be more mistaken and deceived about their task, - the higher ought not to abase itself as the tool of the lower ...". ${ }^{4}$ From the perspective of legislative technique, the pre-war actions of German legislation probably did not evoke any fear. Numerous mechanisms and procedures were introduced that were meant to offer an actual possibility of, e.g., effective appeal from the decision of a sterilisation court. Axiological premises of the law discussed here referred to several fundamental ones, in compliance with which:

- a disabled person is worse;

- a disabled person should be deprived of the possibility of reproduction (protection of the society from transferring defects and disabilities to next generations);

- the state has a right to make arbitrary decisions to protect the society from damages that may be caused by disabled individuals and groups.

A similar approach was justified by a belief that dignity of a disabled person is not subject to any special protection. Thus, deprivation of fertility of a given person was justified by the welfare of the society. However, an assumption that a specific group of people is of lesser quality simultaneously leads to a conclusion that no legal

${ }^{54}$ F. Nietzsche, Z genealogii moralności, Polish translation by J. Borowski, Gdańsk, 2000, p. 56 [English translation: Carol Diethe, Cambridge University Press, 2006]. 
procedures can offer effective defence from violation of human rights. If:

- actions of the legislator;

- judicial practice of courts;

- standards of practising medical profession

rely on a similar, demeaning approach, then no act is capable of guaranteeing protection of human rights, in this case rights of a disabled person.

Unfortunately, when analysing the actions of one of the British courts with respect to a mentally disabled patient, it is difficult to avoid eugenic associations. The judge, approving a forceful abortion with respect to the aforementioned woman, simultaneously decided that it was necessary to intervene in a unique sphere of the patient's life (the sphere of fertility and maternity). The judge, assessing the patient's behaviour, decided that the woman - on account of her disability - would not be able to perform her motherly obligations and simultaneously, by giving birth to the child, she would expose herself to losses in the area of own mental health. It seems that in this case it was not important whether the judge issuing the ruling in the case made a fair assessment of the patient's situation. On the other hand, it is essential that the judge decided on arbitrary intervention in the special area of her life, i.e. the time of her pregnancy. In this case, it did not matter whether the patient had competence to become a mother. However, it was important that the court made a shocking - for many - decision on compulsory abortion due to determining that the woman would not be a competent mother on account of the experienced disability. Unfortunately, similarly to the legislation of the Third Reich, it was decided that certain features disqualify specific people from the role of parents. At the same time, it was decided that such assessment authorised the state to take radical steps. It must be noted that the German law described above allowed not only for sterilisation, but also abortion with respect to disabled people.

In cases reviewed on the basis of the Nazi legislation of the Third Reich, appeals were rarely acknowledged. The above-descri- 
bed British situation found its positive solution. The court of appeals decided that the original judgement was erroneous and allowed for continuation of pregnancy. Let us be hopeful that the basis of such decision was primarily a conviction about the unique character of human dignity, irrespective of the physical or psychical condition of a person. Without a similar approach, no state law can fully guarantee human rights.

\section{Literature}

Ayass W., "Asozialer Nachwuchs ist für die Volksgemeinschaft vollkommen unerwünscht". Die Zwangssterilisationen von sozialen Außenseitern (https://kobra.uni-kassel.de/ bitstream/handle/123456789/2007013016913/Zwangssterilisation.pdf;jsessionid =50FFAF621A85CF83434FC236F3ADD2DD?sequence=3) [accessed: 15 October 2019].

Berndt K., Zwangssterilisationen in Mannheim. Die Rolle der Richter und Ärzte (http:// akjustiz-mannheim.de/Informationen\%20zur\%20Zwangssterilisation $\% 20 \mathrm{im} \% 20$ NS\%20in\%20Mannheim.pdf) [accessed: 14 October 2019].

Bock G., Zwangssterilisation im Nationalsozialismus. Studien zur Rassenpolitik und Geschlechterpolitik (https://refubium.fu-berlin.de/bitstream/handle/fub188/23087 /Zwangssterilisation_im_Nationalsozialismus.pdf) [accessed: 09 December 2019].

Telegram: Brytyjski sąd nakazat aborcje niepetnosprawnej kobiecie, "TVP. Info", source: https://www.tvp.info/43208459/brytyjski-sad-nakazal-aborcje-niepelnospraw nej-kobiecie [accessed: 14 January 2020].

Telegram: U.K. Court of Appeal Overturns Ruling Ordering Mentally Disabled Woman to Have Abortion, "The Wall Street Journal", https://www.wsj.com/articles/u-kcourt-rules-mentally-disabled-woman-must-have-abortion-11561390581 [accessed: 14 January 2020].

Furmankiewicz M, Ziuziański P., "Internet jako źródło danych epidemiologicznych", [in:] Rola informatyki w naukach ekonomicznych i społecznych Innowacje i implikacje interdyscyplinarne, Z.E. Zieliński (ed.), Wydawnictwo Wyższej Szkoły Handlowej Kielce, 2013, pp. 371-381.

Foth T., Regieren durch Akten. Die Funktion von PatientInnenakten für die Krankenmorde des Nationalsozialismus, [in:] Strukturentstehung durch Verflechtung. AkteurenNetwerk-Theorie(n) und Automatismen, ed. T. Conradi, H. Derwanz, F. Muhle, Wilhelm Fink Verlag, München, 2011, pp. 219-235.

Heesch E., Nationalsozialistische Zwangssterilisierungen psychiatrischer Patienten in Schleswig-Holstein (http://akens.org/index.php/materialien-zur-zeitgeschichte/auf 
saetze/18-aufsaetze/euthanasie-zwangssterilisierungen.html) [accessed: 14 October 2019].

Heesch E., Zwangssterilisierungen Kranker und Behinderter in Schleswig-Holstein (http://akens.org/index.php/materialien-zur-zeitgeschichte/aufsaetze/18-auf saetze/euthanasie-zwangssterilisierungen.html) [accessed: 10 December 2019].

Herrmann S.L., Braun K., Das Gesetz, das nicht aufhebbar ist. Vom Umgang mit den Opfern der NS-Zwangssterilisation in der Bundesrepublik (https://www.kj.nomos. de/fileadmin/kj/doc/2010/KJ_10_03_07.pdf) [accessed: 09 December 2019].

Joseph Y., U.K. Court Says Mentally Disabled Woman Must Have Abortion, "New York Times", https://www.nytimes.com/2019/06/23/world/europe/abortion-men tally-disabled-uk.html [accessed: 14 January 2020].

Krajewski M., O metodologii nauk i zasadach pisania naukowego, Płock, 2010.

Loddenkemper R., Konietzko N., Seehausen V., “Die Lungenheilkunde und ihre Institutionen im Nationalsozialismus", Pneumologie 72(02), 2018, p. 106-118.

Mikelionic F., British court overturns ruling forcing disabled pregnant woman to have abortion, "Fox News", https://www.foxnews.com/world/british-overturn-rulingforcing-disabled-pregnant-woman-public-uproar [accessed: 14 January 2020].

Nedoschill J., Castell R., "Kindereuthanasie" während der nationalsozialistischen Diktatur: Die „Kinderfachabteilung“ Ansbach in Mittelfranken”, Praxis der Kinderpsychologie und Kinderpsychiatrie, 50(3), 2001, pp. 192-210.

Puchalski K., "Internet a możliwości poprawy efektów edukacji zdrowotnej”, Studia Edukacyjne, No. 23, 2012, pp. 119-139.

Piechatzek J., Die Auswirkungen des Gesetzes zur Verhütung erbkranken Nachwuchses an der Universitäts-Frauenklinik Kiel in der Zeit von 1932 bis 1940 (https://d-nb. info/1019866705/34) [accessed: 11 December 2019].

Scheulen A., Zur Rechtslage und Rechtsentwicklung des Erbgesundheitsgesetzes 1934 (https://www.bruecke-sh.de/beitrag/anhang/Rechtslage.pdf) [accessed: 15 October 2019].

Sherwood H., Appeal court overturns forced abortion ruling, "The Guardian", https:/ / www.theguardian.com/world/2019/jun/24/catholic-church-hits-out-at-courtover-abortion-ruling [accessed: 14 January 2020].

Schneider H.M., Das nationalsozialistische "Gesetz zur Verhütung erbkranken Nachwuchses" am Beispiel der 1939 an der Psychiatrie Tübingen durchgeführten Sterilisationsgutachten (https://publikationen.uni-tuebingen.de/xmlui/bitstream/handle/10 900/46141/pdf/finale_druckversion_nach_druckfreigabge_und_korrektur_dis _h_schneider_pdf_a_.pdf?sequence=1) [accessed: 10 December 2019].

Spring C.A., Zwischen Krieg und Euthanasie: Zwangssterilisationen in Wien 1940-1945 (http://www.boehlau-verlag.com/download/161614/978-3-205-78321-3_Open Access.pdf) [accessed: 02 December 2019].

Yuhas A., U.K. Appeals Court Overturns Order for Mentally Disabled Woman to Have Abortion, "New York Times", https://www.nytimes.com/2019/06/24/world/ europe/uk-abortion-mentally-disabled-woman.html [accessed: 14 January 2020]. 